Document downloaded from:

http://hdl.handle.net/10251/36667

This paper must be cited as:

Lidón Cerezuela, AL.; Ramos Mompo, C.; Ginestar Peiro, D.; Contreras Espinosa, WA. (2013). Assessment of LEACHN and a simple compartmental model to simulate nitrogendynamics in citrus orchards. Agricultural Water Management. 121:42-53. doi:10.1016/j.agwat.2013.01.008.

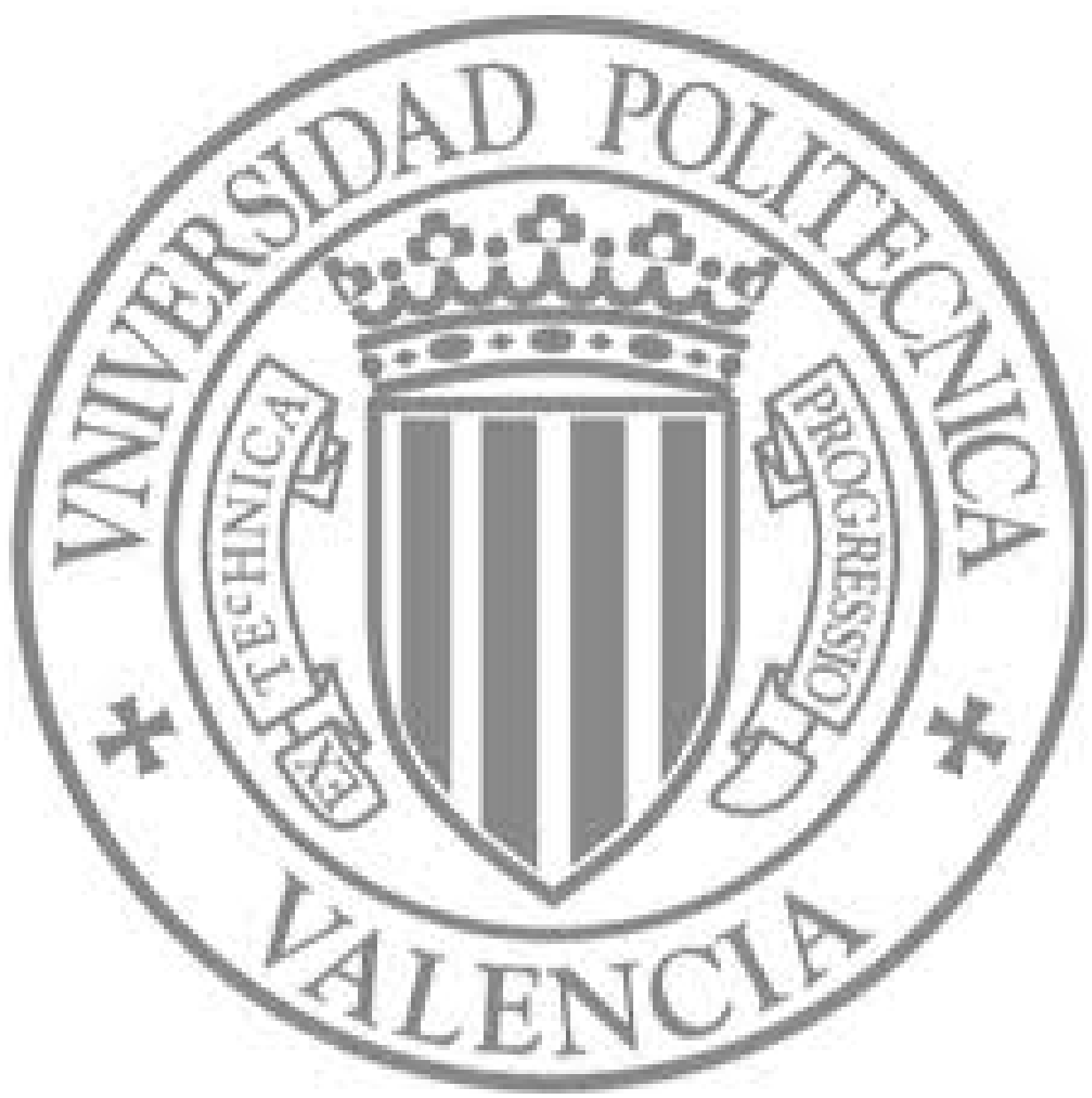

The final publication is available at

http://dx.doi.org/10.1016/j.agwat.2013.01.008

Copyright Elsevier Masson 


\section{Assessment of LEACHN and a simple compartmental model to 2 simulate nitrogen dynamics in citrus orchards}

4 Antonio Lidón ${ }^{\mathrm{a} *}$, Carlos Ramos $^{\mathrm{b}}$, Damián Ginestar ${ }^{\mathrm{c}}$, Wilson Contreras ${ }^{\mathrm{d}}$

5 a Grupo Re-Forest, Departamento de Ingeniería Hidráulica y Medio Ambiente. Universitat Politècnica de

6 València. Camino de Vera, S/N 46022 Valencia, Spain.

$7 \quad{ }^{b}$ Instituto Valenciano de Investigaciones Agrarias, Apdo. Oficial, 46113 Moncada (Valencia), Spain.

$8{ }^{c}$ Instituto de Matemática Multidisciplinar. Universitat Politècnica de València. Camino de Vera, S/N

946022 Valencia, Spain.

$10{ }^{d}$ Departamento de Matemáticas, Facultad de Ciencias Básicas, Universidad de Pamplona, Km 1 Vía 11 Bucaramanga, Colombia.

12 Keywords: Soil nitrogen, nitrate leaching, soil water, fertilization, citrus, LEACHM.

14 Abstract

A simple compartmental model using a tipping bucket approach for the water dynamics coupled with a nitrogen-carbon transformations model has been adapted to simulate the soil nitrogen and water balance in mature orange groves on a daily step. This model has been compared with the more mechanistic LEACHN model (the $\mathrm{N}$ module of the LEACHM model), which uses Richards' equation to simulate soil water movement in unsaturated conditions, the convectiondispersion equation for solute transport, and that, in addition to including evapotranspiration, $\mathrm{N}$ transformations and $\mathrm{N}$ plant uptake as in the compartmental model, it also considers gaseous losses due to denitrification and ammonia volatilization, that are not considered in the compartmental model. This comparison was made using data from a three-year experiment in a citrus orchard with two nitrogen fertilization rates. After calibration using the first year data, a reasonable match between simulated and measured values in both models was observed for soil water storage in the whole profile for the validation period $\left(2^{\text {nd }}\right.$ and $3^{\text {rd }}$ year $)$, but the agreement was not so good for the soil mineral nitrogen content. In spite of the differences in the nature and in the complexity of the two models, the soil water dynamics and drainage were well simulated during the whole period by both models. However, the LEACHN model predicted nitrate leaching better than the compartmental model, probably because it considers the nitrogen cycle in a more detailed way. This work is the first calibration and performance evaluation of

\footnotetext{
* Corresponding author. E-mail: alidon@qim.upv.es. Tel.: 34 963877346; fax: 34963877139
} 
1 the LEACHN model for citrus in the Mediterranean area and the results obtained in this study 2 indicate that this model can be a valid tool to evaluate the effects of irrigation and $\mathrm{N}$ 3 management on nitrate leaching. The compartmental model has a lower data requirement and calibration is less complex than the LEACHN model and, therefore, may be more appealing for advisory $\mathrm{N}$ management purposes.

\section{Introduction}

9 Nitrogen is an important nutrient in agricultural systems but inadequate management of 10 nitrogen fertilizers and irrigation, especially in areas of intensive agriculture under irrigation and with important inputs of nitrogen fertilizer, may result in major environmental problems such as nitrate leaching or nitrous oxide emissions to the atmosphere (Alva et al., 2006;

13 Neeteson and Carton, 2001; Quiñones et al., 2007). Nitrate pollution of groundwater is a worrying problem in many irrigated areas in Spain (MMA, 2006). Ground water is used for irrigation in $27 \%$ of the irrigated agricultural land, and also provides $40 \%$ of the drinking water. In some areas of the coastal plain in the Valencia region nitrate concentration in groundwater is greater than $100 \mathrm{mg} \mathrm{NO}_{3}{ }^{-} \mathrm{L}^{-1}$ (MMA, 2004). In this region there are 178000 ha of citrus, representing about $32 \%$ of the cultivated land, of which about 77000 ha are sweet orange with a fruit production of about $1.9 \mathrm{Mt} \mathrm{year}^{-1}$. The most common irrigation system in this area is flood irrigation although drip irrigation is increasing. The irrigation water use for this crop in this region is about $750-900 \mathrm{~mm}$ year $^{-1}$ (Castel et al., 1987). With respect to nitrogen fertilization, some authors have established that the annual nitrogen requirement of citrus in the Valencia region is between $600-800 \mathrm{~g} \mathrm{~N}^{-1} \mathrm{e}^{-1}$ (Primo-Millo and Legaz, 1993), approximately equivalent to $240-300 \mathrm{~kg} \mathrm{~N} \mathrm{ha}^{-1}$, that is somewhat higher than the $200-250$ $\mathrm{kg} \mathrm{N} \mathrm{ha}{ }^{-1}$ year $^{-1}$ recommended by the Valencian Code of Good Agricultural Practices (VCGAP) (DOGV, 2010) for citrus under flood irrigation. However, there is still a large variation in the nitrogen fertilization rates applied by farmers.

Different studies dealing with nitrate leaching in citrus have quantified the losses of nitrate for different fertilization practices (Lamb et al., 1999; Paramasivam et al., 2001; Ramos et al., 2002). These studies show that for nitrogen application rates up to $400 \mathrm{~kg} \mathrm{~N} \mathrm{ha}^{-1}$ year $^{-1}$, nitrate leaching rate was, in most cases, less than $100 \mathrm{~kg} \mathrm{~N} \mathrm{ha}^{-1}$ year $^{-1}$. In general, nitrate leaching losses increased with fertilizer nitrogen application rate and the amount of water drained, and accounted for up to $33 \%$ of the total applied nitrogen. Although in different agricultural systems there seems to be a direct relationship between nitrogen inputs and the increasing concentration 
1 is difficult to measure, since it is affected not only by water flow but also by all the $\mathrm{N}$ 2 transformations that take place in soil (mineralization, immobilization, denitrification, plant 3 uptake, etc.).

4 To attain higher nitrogen use efficiency, it is necessary to improve both nitrogen fertilization 5 and irrigation management. Computer simulation models can help in this improvement because 6 they integrate the different processes affecting the nitrogen dynamics in the soil-plant system.

7 Some nitrogen models in the soil-plant system are LEACHM (Wagenet and Hutson, 1989), 8 SOILN (Hoffmann and Johnsson, 1999), STICS (Brisson et al., 1998) and WAVE (Vanclooster 9 et al., 1996). These models, after calibration, allow the estimation of nitrate leaching, soil 10 mineral nitrogen and water content for different crops under different conditions of irrigation, 11 rainfall and fertilization, being an inexpensive and rapid technique to evaluate the effects of 12 various agricultural management practices on nitrate leaching (Cannavo et al., 2008; Kersebaum 13 et al., 2007).

14 The LEACHM model has been widely used and validated for several annual crops (Jabro et al., 15 1995; Webb and Liburne, 1999). However, it has hardly been used with perennial plants. 16 Harrison et al. (1999) used the LEACHM model for evaluating the long-term impacts of 17 alternative citrus nitrogen and water management practices on the Central Florida Ridge. Alva 18 et al. (2006) used the LEACHM model to estimate the $\mathrm{N}$ budget components for different 19 nitrogen and irrigation practices for citrus in sandy soils in Florida.

20 In this paper it is assumed that a simpler model capable to obtain good predictions of water and soil nitrogen dynamics in citrus orchards, would be more appealing for advisory purposes. From a practical point of view, the main problem of using simulation models such as LEACHM is that many experimental data are needed for their calibration (Jung et al., 2010) and this is probably the reason why they are barely used for irrigation and $\mathrm{N}$ fertilization management in commercial orchards. Thus, simpler models with fewer data requirements could be of interest for estimating the water and nitrogen needs in farmer fields and at a regional scale (Nendel, 2009). For this reason, a compartmental model developed by Contreras et al. (2009) that combines a simple soil water capacity module with an analytical model for the carbon and nitrogen dynamics developed by Porporato et al. (2003) was selected. This later model was applied in the broad-leafed savannah at Nylsvley (S. Africa) (D’Odorico et al., 2003) coupled with an existing stochastic soil moisture model and provided good results. The two main goals of this study were (1) to adapt the LEACHN and the compartmental models to be used on citrus orchards, and (2) to calibrate them and assess their performance using data from a 3-year experiment with two $\mathrm{N}$ fertilization treatments. This work constitutes the first calibration and validation of LEACHN model in citrus orchards in the Mediterranean area. 


\subsection{LEACHN model for citrus}

6 LEACHN is the nitrogen module of the LEACHM model. LEACHM (Leaching Estimation And

7 Chemistry Model) is a process-based, one-dimensional model that simulates water and solute 8 movement, and related chemical and biological processes, in the unsaturated soil (Wagenet and 9 Hutson, 1989). A summary of the main terms of water and nitrogen balance and their treatment 10 by the LEACHN model is presented in Table 1 . The model describes the one-dimensional water 11 flow in the unsaturated zone using the Richards' equation. Solute transport is modeled by the 12 convection-dispersion equation, and the main processes described in the nitrogen module are 13 mineralization, nitrification, denitrification and volatilization.

14 Input data for the LEACHN model include soil physical and chemical properties for the 15 different soil layers as well as weather and crop data. The soil physical properties include: bulk 16 density, hydraulic conductivity and water retention curve parameters. The water flow routine in 17 LEACHN uses equations proposed by Campbell (1974) to relate volumetric water content, 18 pressure potential and hydraulic conductivity. The evapotranspiration calculation is based on the 19 method proposed by Childs and Hanks (1975) using weekly data of the class A pan evaporation $20 E_{o}$, the pan coefficient $k_{p}$, and a crop coefficient $k_{c}$. Potential crop evapotranspiration is calculated as $E_{o} \cdot k_{p} \cdot k_{c}$. Soil chemical properties required by the model include: initial organic carbon, organic and inorganic nitrogen contents, and rate constants for the N-transformation 23 processes.

24 To apply LEACHN to citrus orchards, the nitrogen plant uptake module had to be modified 25 since, in its original form, LEACHN only considers $\mathrm{N}$ uptake in annual crops. The model 26 requires the potential annual $\mathrm{N}$ uptake by the crop, but since it calculates this uptake on a daily 27 basis, it is necessary to obtain the potential daily values. These were estimated based on the 28 seasonal uptake pattern measured by Legaz and Primo (1988). According to these authors the maximum monthly $\mathrm{N}$ uptake in the Valencia region is in July (about $43 \mathrm{~kg} \mathrm{~N} \mathrm{ha}^{-1}$ ) and the minimum is in January (about $3 \mathrm{~kg} \mathrm{~N} \mathrm{ha}^{-1}$ ). The seasonal $\mathrm{N}$ uptake pattern observed by Legaz and Primo (1988) was transformed in a cumulative curve throughout the year, and the potential $\mathrm{N}$ uptake for a given day was calculated as a fraction (FTNU) of the total annual uptake using the following polynomial regression model: 


$$
\begin{aligned}
& \text { FTNU }=-1.1447 \text { FGS }^{6}+3.6476 \text { FGS }^{5}-4.2331 \mathrm{FGS}^{4}+2.1291 \mathrm{FGS}^{3} \\
& -0.4314 \mathrm{FGS}^{2}+0.033 \text { FGS }
\end{aligned}
$$

2

where FGS is the fraction of the year passed from the $1^{\text {st }}$ of January till that day. This regression model, had a coefficient of determination $\left(\mathrm{R}^{2}\right)$ of 0.98 , and satisfies that when FGS is zero FTNU is also zero, to eliminate the possible negative values for $\mathrm{N}$ uptake.

\subsection{Compartmental model}

This model computes the soil nitrogen balance in a mature orange grove on a daily step and is described in Contreras et al. (2009). The model resulted from the coupling of a compartmental model of the nitrogen dynamics in the soil, developed by Porporato et al. (2003), with a simple soil water capacity model described in Lidón et al. (1999). A summary of the main terms of water and nitrogen balance and their treatment by the compartmental model is presented in Table 1.

The water module uses a 'tipping bucket' approach in the root soil profile, which is a simplified scheme for calculating soil water content, which requires a relatively small number of input parameters in comparison to a scheme using Richards' equation (Emerman, 1995). Several modifications were made to implement a soil profile consisting of three layers of different thickness, layer $1(0-30 \mathrm{~cm})$, layer $2(30-60 \mathrm{~cm})$ and layer $3(60-80 \mathrm{~cm})$, according to the scheme shown in Fig. 1. Changes in the calculation of the different components of water balance with respect to the original one-layer model are as follows: a) percentage of the root distribution in each soil layer has to be given as an input and this is used when calculating root water uptake from each layer; b) irrigation and rainfall inflow is considered only in the first layer; c) if the water content of the first layer exceeds maximum allowed soil water storage, then this excess is considered runoff; d) if the water content exceeds field capacity, then this excess of water drains into the underlying layer; and e) drainage from a layer is a water input to the layer below (Contreras et al., 2009).

The nitrogen module considers five $\mathrm{N}$ pools and their relations are described in Contreras et al. (2009). The model assumes that nitrogen losses by volatilization and denitrification are similar to the atmospheric deposition and biological fixation, and none of these are considered. This simplifying assumption has also been used by other authors (Jeuffroy and Recous, 1999). Other assumptions are: a) mineral nitrogen inputs for rainfall, irrigation and fertilizers are inputs only for the first layer; b) the inputs to the following layer are only due to mineralization and nitrate leaching from the above layer; $c$ ) the calculated nitrogen uptake is compared with the potential 
1 daily uptake of $\mathrm{N}$ for an adult orange tree, and the lower of these two values is taken.

5 Data used to calibrate and validate the two simulation models were obtained from a three year

\subsection{Field experiment}

experiment conducted in a commercial citrus orchard in the Valencia province of Spain $\left(39^{\circ} 30^{\prime} 18^{\prime \prime} \mathrm{N}, 0^{\circ} 23^{\prime} 01^{\prime}\right.$ 'W, 14 meters above sea level). The main objective of the experiment was to evaluate the effects of different $\mathrm{N}$ fertilization rates on fruit yield and nitrate leaching. Table 2 summarizes the main characteristics of the field experiment, while selected physical and chemical properties of this soil are shown in Table 3. In this paper, data are from two $\mathrm{N}$ fertilizer treatments: $\mathrm{N} 1\left(150 \mathrm{~kg} \mathrm{~N} \mathrm{ha}^{-1}\right.$ year $\left.^{-1}\right)$, and N2 (300 kg N ha ${ }^{-1}$ year $\left.^{-1}\right)$ that correspond to rates about $75 \mathrm{~kg} \mathrm{~N} \mathrm{ha}^{-1}$ lower and higher, respectively, than that recommended by the VCGAP (200-250 kg N ha ${ }^{-1}$ year $\left.^{-1}\right)$.

4 Nitrate leaching at a given depth and for a period was calculated as the product of the drainage 5 for this period and the mean nitrate concentration of the soil solution to the depth considered. 6 Drainage was calculated by a chloride balance (Lidón et al., 1999), since this method has some 17 advantages over the water balance method. In the latter approach any reduction in 8 evapotranspiration produced by water deficits or other causes (nutrient deficiencies, pests, etc.) 9 are difficult to assess. The chloride balance method is not influenced by these factors and it is relatively simple to use. In this method the main $\mathrm{Cl}^{-}$inputs considered are the irrigation water and, in some cases, potassium fertilisers, and the main outputs are: drainage, plant uptake, and change in soil content. Chloride uptake by citrus trees was estimated from Lidón et al. (1999) and was considered to be uniform throughout the year. There are two major sources of uncertainty in this balance: 1) the high variability in the soil chloride content, and 2) the assumption of a linear change in the chloride concentration of the draining soil solution at the bottom plane of the soil layer considered in the balance from the beginning to the end of the period considered. Ramos (1988) and Lidón et al. (1999) reviewed the application of this method for drainage estimation and concluded that the effects of a high spatial variability of chloride content in soil are less important when the chloride input is large relative to the amount of chloride in the soil profile, and that at depths greater than about $60 \mathrm{~cm}$, the variation of chloride concentration with time can be considered approximately linear for periods of 1-2 months. Evapotranspiration was calculated by a water balance in which drainage was obtained by a chloride balance, and runoff was assumed to be zero (this assumption is reasonable, since the irrigation units were leveled basins surrounded by ridges about $15 \mathrm{~cm}$ high). 
3 Calibration of both models was performed using data from the higher $\mathrm{N}$ rate fertilizer treatment,

4 N2, for the first year. First, the water module was calibrated and, after this, the nitrogen module parameters were adjusted as described below. Data from the first year were used for calibration because during this year there were more soil mineral data available for the irrigation and fertilization season, and this provided a wider range of water and nitrogen contents.

8 Some assumptions were made in the use of both models. For the citrus orchard used in the 9 experiment, a potential annual $\mathrm{N}$ uptake of $200 \mathrm{~kg} \mathrm{~N} \mathrm{ha}^{-1}$ was assumed. Although this parameter 10 has a great influence on the other components of the nitrogen balance, especially when soil water and mineral nitrogen are not limiting, it was decided not to calibrate it because this assumed value is very close to that measured by Legaz and Primo (1988) for citrus trees of similar age and size in the same Mediterranean area. Also, it was assumed that the soil organic $\mathrm{C}$ content was in equilibrium since the experimental orchard had trees 20 years old, and a relatively constant management over the time. In addition, since citrus are perennial plants, it was considered that the leaf litter input kept constant the soil organic matter content during the simulation period. Leaf litter input to the soil surface was taken as $2350 \mathrm{~kg} \mathrm{C}^{-1} \mathrm{year}^{-1}$ with a $\mathrm{C} / \mathrm{N}$ ratio of 28 , representing an annual input of $85 \mathrm{~kg} \mathrm{~N} \mathrm{ha}^{-1}$ year $^{-1}$ (Harrison et al., 1999). The $\mathrm{C} / \mathrm{N}$ ratio of the plant residues annually added to the soil as litterfall, microbial biomass and litter were estimated from Moreno (2001), Ferrer et al. (2006) and Brady and Weil (2002). For the water module of the LEACHN model the parameters used were those proposed by Lidón et al. (1999) for this same orchard, with minor changes. A free-draining lower boundary was assumed, since the depth of the groundwater was 3-4 meters as indicated by the water level of nearby wells. The pan coefficient to calculate evapotranspiration was set to $k_{p}=0.815$ (Doorenbos and Pruitt, 1977) and the monthly values of $k_{c}$ for citrus in the Valencia region were based on Castel et al. (1987), and are given in Lidón et al. (1999). The fraction of ground cover by the trees was taken as 0.85 . The root resistance parameter was varied until a good fit of the simulated water content in the soil profile was obtained. Root distribution with soil depth was assumed to follow the pattern described by Ayers and Wescott (1985) for water uptake by plants, but slight modifications were introduced to obtain a good fit of the simulated water content in the soil profile to the measured values. The saturated hydraulic conductivity $\left(k_{s}\right)$ of the soil layers was calculated following Ahuja and Nielsen (1991). Some other parameters of the water retention curve could have been changed instead, but it was decided to vary only $k_{s}$, since this parameter is the main factor determining drainage flux in a low permeability layer where water content is often close to saturation. Soil hydraulic and crop parameters used in 
LEACHN are presented in Table 4.

2 Soil hydraulic parameters required by the compartmental model were initially estimated using

3 Saxton et al. (1986) approach. For the calibration of the water module of this model, the

4 guidelines given by Lidón et al. (1999) for each soil layer $(0-30 \mathrm{~cm}, 30-60 \mathrm{~cm}$ and 60-80 cm)

5 were followed. Minimum soil water content was initially set equal to a typical water content

6 value measured in the soil profile just before irrigation. The maximum soil water storage held

7 against gravity was taken as the average soil water content measured 3-5 days after irrigation.

8 The initial maximum soil water storage estimate was taken as the water content at saturation in

9 the first $50 \mathrm{~cm}$, plus $5 \mathrm{~cm}$ to account for the possibility of water ponding due to ridges in the

10 irrigation basins. All these values were then adjusted to improve the fit between predicted and

11 measured soil water content in each layer and drainage, using data measured in periods with

12 large soil water changes during first year. Initial values of root distribution before calibration

13 followed the distribution used in different studies, but the root distribution was slightly modified

14 from that used in the LEACHN model to better fit the experimental data. Other parameters used

15 in the compartmental model and not subject to calibration are listed in Table 5.

16 To find the most influential parameters of nitrogen dynamics determining the soil mineral 17 nitrogen content in the LEACHN model, a sensitivity analysis was performed following 18 Sogbedji et al. (2001, 2006). Multiple runs of the model were performed in which changes of 19 each parameter selected were made. The ammonium and nitrate soil content and nitrate leaching 20 were affected by changes in the potential annual $\mathrm{N}$ uptake and by changes in the rate constants 21 for mineralization, nitrification, ammonia volatilization from surface, and denitrification. The 22 measured mineral nitrogen content in each layer was the variable used in the calibration process 23 for $\mathrm{N}$ parameters. The sensitivity analysis showed that the most important parameters were: 24 potential annual $\mathrm{N}$ uptake, native organic matter mineralization rate constant, synthesis 25 efficiency factor and humification fraction, ammonia volatilization, denitrification, nitrification 26 and litter mineralization rate constants. Adjustment of the selected parameters followed the 27 order: the humification fraction, the rates of nitrification, denitrification and mineralization of 28 litter, and finally the rate of mineralization of humus and the synthesis efficiency factor.

29 In the compartmental model respiration and humification fraction, microbial biomass death rate 30 and partition nitrogen coefficients were obtained from D'Odorico et al. (2003). For the nitrogen 31 module the calibration process was started with those parameters with a similar meaning in the 32 LEACHN model and they were varied to obtain the best fit with the measured soil nitrogen 33 mineral content.

34 Calibration of a given parameter was finished when further adjustments no longer reduced the 35 difference between measured and simulated data using the root mean squared error (RMSE) 
1 given by

$$
R M S E=\sqrt{1 / N \sum_{i=1}^{N}\left(D_{i}\right)^{2}}
$$

3 where $D_{i}$ is the difference between the measured value $\left(Y_{i}\right)$ and the corresponding value

4 calculated by the model $\left(\hat{Y}_{i}\right)$, and $N$ is the total number of values of soil water and mineral 5 nitrogen content. This procedure was performed for each soil layer starting with the top layer.

6 To assess the accuracy of the calibrated model, simulated values were plotted against the 7 corresponding measured values on a 1:1 graph, and the correlation coefficient (r) and the mean 8 difference between simulated and measured data were used as criteria to evaluate the model 9 predictions. In addition, other indices have been computed such as the relative root mean square 10 error (RRMSE) and the agreement index (AI) described in Wallach (2006) and given by,

$$
R R M S E=\frac{R M S E}{\bar{Y}}
$$

$$
A I=1-\frac{\sum_{i=1}^{N}\left(Y_{i}-\hat{Y}_{i}\right)^{2}}{\sum_{i=1}^{N}\left(\left|\hat{Y}_{i}-\bar{Y}\right|+\left|Y_{i}-\bar{Y}\right|\right)^{2}}
$$

15 where $\bar{Y}$ is the average of the $Y_{i}$ values.

16 Validation of both models was performed using data from the second and third years of treatment N2, and from the three years for treatment N1. For this purpose, measured values of the soil water content of the different layers and the amount of water stored in the whole soil profile, drainage, soil mineral $\mathrm{N}$ content, and nitrate leaching were compared with the simulated values. The statistical indices listed above were then obtained.

\section{Results and discussion}

\subsection{Models calibration}

The calibrated water parameters, $\mathrm{N}$ transformation rate constants and other adjusted parameters are presented in Table 6. Differences between some parameter values for both models are due to the different meanings they have in each model. For example, in the compartmental model the 
1 rates of litter and humus decomposition and the nitrification depend on soil moisture and the 2 microbial biomass content, whereas in the LEACHN model nitrogen mineralization rates 3 depend upon the rate of decomposition of the organic $\mathrm{C}$ pools, the $\mathrm{N}$ content of these pools, and 4 the $\mathrm{C} / \mathrm{N}$ ratio of the decomposition products, and nitrification proceeds at a potential rate 5 decreasing until a given maximum $\mathrm{NO}_{3}{ }^{-} / \mathrm{NH}_{4}{ }^{+}$concentration ratio is achieved (Johnsson et al., 6 1987).

7 After calibration, simulated and measured soil water storage values for the three soil layers 8 were, in general, close in both models (Table 7), but the LEACHN model overestimated soil 9 water content, whereas the compartmental model tended to underestimate it (Fig. 2). Both 10 models gave a high correlation coefficient (r) and agreement index (AI) in the surface layer (0$1130 \mathrm{~cm}$ ), probably because this layer has the highest temporal variation, and this improves the 12 calibration. The fit obtained in the second and third layers is not as good as in the surface layer, 13 probably due to a lower range of variation of soil water content that made calibration less 14 accurate (Fig. 2). On the whole profile, the prediction error (RRMSE) was $11 \%$ for the 15 LEACHN model and $8 \%$ for the compartmental model, with a correlation coefficient similar in both models. The high values of the $A I$ for LEACHN and for compartmental model indicate a good match between simulated and measured data for the calibration period.

18 For the calibration period, soil water storage simulated by LEACHN was more responsive to water application than in the compartmental model (Fig. 3), and the influence of the hydraulic properties of a given layer on the water content of another layer was also greater in the LEACHN model. This is due to the different treatment of water dynamics in both models: while in the compartmental model, the water exceeding field capacity value is attributed immediately to drainage, in the LEACHN model water flow is determined by Richards' equation, that uses the hydraulic conductivity as a key variable, and soil water content changes in the lower soil layers after an irrigation or rainfall event can take several days. These effects on soil water flow in the LEACHM model might explain the overestimation of water storage values at the end of the irrigation period and the beginning of the rainy season, if the assigned saturated hydraulic conductivity for the $60-80 \mathrm{~cm}$ layer was lower than the real value. The calculated $k_{s}$ for the deepest soil layer, following Ahuja and Nielsen (1991), was very low, and this resulted in much lower drainage values in comparison to those obtained by chloride balance. To correct for this, the $k_{s}$ for this layer was increased to obtain a better fit between the simulated and measured soil chloride content during the first year, since soil chloride content depends on drainage. The compartmental model does not account for these hydraulic conductivity effects, but despite this and although its calibration was simpler, the results were acceptable.

35 For the soil mineral nitrogen content (Table 7 and Fig. 2), although RRMSE showed that the 
1 agreement between measured and simulated data was not as good as for soil water content, the

2 AI indicated that the agreement for the whole profile was good and similar for both models. The

3 worst fit occurred again in the third layer, as shown by the low agreement index obtained for

4 this layer. In this layer the main process governing the $\mathrm{N}$ dynamics is nitrate leaching that

5 depends strongly on the water flow, and the calibration of the $\mathrm{N}$ transformation parameters is

6 less important.

7 The lower agreement between observed and simulated values for the soil nitrogen content in

8 both models is not surprising since there are many processes involved in the nitrogen cycle

9 (including water movement). In addition, in the compartmental model the temperature and soil

10 moisture effects on some parameters are not taken into account. In the $60-80 \mathrm{~cm}$ soil layer,

11 differences between measured and simulated $\mathrm{N}$ content values were larger in both models,

12 reflecting probably the accumulation of simulation errors when going from the upper to the

13 deeper soil layers, as well as the difficulties in calibrating the hydraulic parameters for these

14 layers for the reasons mentioned before.

\subsection{Models validation}

18 In the validation test both models predicted soil water content even better than in the calibration 19 period, but for soil mineral nitrogen content the agreement between measured and simulated 20 values was worse than for water, and slightly better for the N2 treatment (Table 7), probably because calibration used N2 treatment data. Fig. 3 shows the measured and simulated soil water storage and cumulative drainage at $80 \mathrm{~cm}$ for both models in the whole period. In this case, there are no differences between $\mathrm{N}$ treatments because the water input was the same in both treatments. It can be seen that both models fit the data well in the first year of the validation period, but that in the last year the LEACHN model underestimates drainage.

A comparison of the measured and simulated soil water balance components values is presented in Table 8. It can be observed that the simulated cumulative ETc for the 3-year period and the annual values were close to the measured values in both models, except for the third year in the LEACHN model where there was an overestimation of about $10 \%$. Simulated drainage was within $14 \%$ from the measured values for the two models in the first two years, and only in the third year the LEACHN model underestimated drainage grossly. Although drainage obtained by chloride balance method has some uncertainties (see Lidón et al., 1999), these are mitigated in this case because the chloride balance is calculated from several points ( 3 points per tree, 2 trees per treatment, and 2 treatments), and because soil was sampled several times throughout the year. This provided a chloride balance for each sampling period, and annual drainage was 
1 obtained as the sum of drainage in each period.

2 Simulated runoff was relatively small in all cases (less than $6 \%$ of total water input). In the

3 compartmental model runoff is calculated from the maximum soil water storage, while in the

4 version of LEACHN model used in this paper runoff is the water that cannot infiltrate in the

5 time step considered. Although runoff was not measured it is unlikely that it was important

6 because of the ridges (about $10-15 \mathrm{~cm}$ high) surrounding the irrigation units that prevent the

7 generation of runoff, except when heavy rains occur. In the soil water balance (Table 8), the

8 variation of soil water storage is small relative to the other terms, and can be considered 9 negligible for long periods of time.

10 An estimate of irrigation efficiency was obtained calculating the ratio 11 evapotranspiration/applied irrigation water, during a long period of the main irrigation season, 12 when the rains were not significant. Very high values were obtained (even higher than $100 \%$ ) 13 indicating that irrigation applied by the farmer was lower than required $(221-413 \mathrm{~mm}$ as 14 compared to $450-520 \mathrm{~mm}$ that is considered normal in this period (Castel et al., 1987)). These 15 water deficits must have induced a reduction in actual evapotranspiration during some period in 16 summer, and therefore an upward water flow from the soil layers below the $80 \mathrm{~cm}$ depth (soil 17 moisture in the $80-150 \mathrm{~cm}$ soil layer was always greater than that of the $60-80 \mathrm{~cm}$ layer (data 18 not shown)).

19 For the validation period both models reproduced relatively well the measured values of soil 20 mineral nitrogen content in both $\mathrm{N}$ treatments, although a slight underestimation was observed in the N1 treatment (Fig. 4). The errors associated with both models (RRMSE) for the N1 and

$22 \mathrm{~N} 2$ treatments were similar, but the agreement indices for N1 were lower than for N2 (Table 7).

23 The main components of the $\mathrm{N}$ budget for the two $\mathrm{N}$ treatments are given in Table 9. Simulated plant uptake was the major $\mathrm{N}$ output term, accounting for $72-77 \%$ of the total $\mathrm{N}$ output for treatment $\mathrm{N} 1$ and $61-63 \%$ for treatment N2. For treatment N1, simulated plant uptake was greater than total input (in fertilizer and irrigation water) indicating that the citrus trees had to use part of the initially available soil mineral nitrogen and that produced by mineralization. The differences in the $\mathrm{N}$ plant uptake in both models are probably due to the different soil nitrogen content simulated by both models, to the different algorithms used for $\mathrm{N}$ plant uptake, and to the differences in the simulated evapotranspiration. In the LEACHN model $\mathrm{N}$ uptake (nitrate and ammonium) occurs in the transpiration stream but it cannot exceed the potential $\mathrm{N}$ uptake. If this uptake does not satisfy the plants requirements, then a diffusive component for nitrate only is calculated. In the compartmental model $\mathrm{N}$ plant uptake is calculated solely as a function of $\mathrm{N}$ concentration in the soil solution and root water uptake.

35 Mineralization values estimated by both models were, on average, about 100 and $125 \mathrm{~kg} \mathrm{~N} \mathrm{ha}{ }^{-1}$ 
1 year $^{-1}$ for the compartmental and LEACHN models, respectively. These values are within the 2 range measured by Dou et al. (1997) for the 20-yr-old citrus trees growing in Florida with sandy 3 soils and organic matter content ranging from $10-27 \mathrm{~g} \mathrm{~kg}^{-1}$, and those reported by Lidón et al 4 (2006) in an area close to the experimental plot, with a similar soil but cultivated with vegetable crops. These results indicate that mineralization provides a significant portion of the annual $\mathrm{N}$ requirement. The steady state assumption for the humus compartment considered in this paper is supported by results in the compartmental model, which simulated only a $0.6 \%$ reduction in the initial content of soil organic nitrogen over three years, whereas the LEACHN model simulated this reduction was of $1.5 \%$, indicating that to achieve equilibrium in soil $\mathrm{N}$ humus content, it would be necessary to increase the fraction of litter that is transformed into humus. Gaseous losses of $\mathrm{N}$ by $\mathrm{NH}_{3}$ volatilization simulated by the LEACHN model represented $9 \%$ and $11 \%$ of applied $\mathrm{N}$ in the $\mathrm{N} 1$ and $\mathrm{N} 2$ treatments, respectively. These values are within the range reported by Alva et al. (2006) for a citrus grove fertilized with ammonium nitrate and urea and with a fine sand soil with a $\mathrm{pH}$ of 6.0 for the surface layer. The low denitrification values simulated by the LEACHN model are consistent with the experimental conditions: well-drained soils, with only a few days of irrigation or heavy rains during which some gaseous losses could occur (Paramasivam et al., 1999).

18 Measured nitrate leaching represented about $30 \%$ of the total nitrogen input in both $\mathrm{N}$ treatments for the whole period. Since both treatments had the same drainage, because the water input was the same for both $\mathrm{N}$ treatments, the leaching differences observed reflect the different nitrogen input in each treatment (Fig. 4). Nitrate leaching increased with $\mathrm{N}$ fertilization, and was well predicted by the LEACHN model, but the compartmental model overestimated it by $60 \%$ and $49 \%$ in treatments $\mathrm{N} 1$ and $\mathrm{N} 2$, respectively. Looking at the simulated leaching for the different years for the compartmental model, it becomes apparent that it is in the second year when the differences between measured and simulated values are greater. This is also observed with the LEACHN model but much less pronounced (Table 9), and there are not clear reasons for this overprediction in both models. With respect to the differences in nitrate leaching between the two models, it is possible that these are due to the higher drainage simulated by the compartmental model and to a higher availability of soil nitrate in this model, probably because it does not consider volatilization nor denitrification losses. However, the LEACHN model simulated a higher mineralization than the compartmental model, and this would increase nitrate leaching, contrary to what is observed. Despite these differences in nitrate leaching, both models gave similar total $\mathrm{N}$ losses.

34 These results indicate that the LEACHN model predicted nitrate leaching better than the 35 compartmental model, probably because it considers the nitrogen cycle in a more detailed way 
1 and includes processes such as volatilization, denitrification and accounts also for temperature

2 effects on the $\mathrm{N}$ related rate constants.

\subsection{Using the models to improve $N$ management}

6 Once calibrated and validated both models, different fertilization and irrigation management practices were assessed considering only the environmental aspects (nitrate leaching and gaseous nitrogen emissions), since agronomic effects on yield or tree growth are not included in both models, and can only be estimated indirectly by looking at the simulated soil mineral $\mathrm{N}$ availability and the $\mathrm{N}$ uptake, that can be lower than the potential uptake and, therefore, limit 11 yield and growth.

12 Table 10 shows the scenarios considered, in which irrigation rate, $\mathrm{N}$ fertilizer rate, the chemical 13 form of nitrogen used and the number of fertilizer applications were varied. Nitrate leaching, $\mathrm{N}$ 14 plant uptake and other $\mathrm{N}$ losses, as volatilization and denitrification, obtained in each of the scenarios are compared with results obtained with conventional management ( $\mathrm{N} 2$ in field experiment). The simulation period included the three year period used in the evaluation of the models.

18 The results show that the variation in the irrigation rate $( \pm 10 \%)$ produced changes in drainage and therefore in nitrate leaching (Fig. 5). Increasing irrigation causes increased nitrate leaching (9\%), whereas reducing irrigation decreased it by $6-8 \%$ without affecting $\mathrm{N}$ plant uptake. The decrease in the $\mathrm{N}$ fertilizer rate affected different outputs of nitrogen balance. A reduction of $10 \%$ in $\mathrm{N}$ rate produced a similar reduction of nitrate leaching, in both models (Fig. 5, Sc3), but this did not affect $\mathrm{N}$ plant uptake. In this case, the LEACHN model also predicted a reduction of volatilization (12\%) and denitrification (15\%). Using ammonium nitrate instead of ammonium sulphate did not affect nitrate leaching but reduced volatilization (6\%). Increasing the number of $\mathrm{N}$ applications and reducing the total $\mathrm{N}$ rate resulted in a greater nitrate leaching reduction. Using the $\mathrm{N}$ fertilizer rate recommended by the current regional legislation (DOGV, 2008) reduced nitrate leaching by $19 \%$ (Fig. 5, Sc7), while N plant uptake was barely affected. The combined effect of the reduction in irrigation and nitrogen rates resulted in an important nitrate leaching reduction of $17-25 \%$ (Fig. 5, Sc6 and Sc10), similar to the sum of the reduction caused by irrigation and fertilization separately, in both models.

32 Additional examples on the use of the LEACHN model for $\mathrm{N}$ management in citrus orchards in the Valencia region are given in Lidón and Paches (2005).

\section{Conclusions}


1 Two different models to simulate water and nitrogen dynamics in a soil profile have been 2 adapted for their use on citrus orchards and assessed using data from a three-year field 3 experiment with two nitrogen application rate treatments in a commercial citrus orchard in the 4 region of Valencia (Spain): a compartmental model using a tipping bucket approach for the 5 water dynamics and a transport model based on the solution of physical equations governing the 6 movement of water and solutes in soils.

7 After calibration, the compartmental and LEACHN models gave relatively good estimations of soil water content in the whole period. The compartmental model predicted drainage better than the LEACHN model, and the simulated evapotranspiration was similar in both models. With respect to the soil mineral $\mathrm{N}$, the LEACHN model predicted well the measured values for the

12 decreased in both $\mathrm{N}$ treatments. The compartmental model gave good predictions for the soil 13 mineral nitrogen content, but overpredicted nitrate leaching.

14 Calibration of the compartmental model is easier than that of LEACHN and this is important if 15 the model is to be used as an advisory tool for crop management in commercial orchards. Improvement of the compartmental model could be done by: a) introducing some algorithms to simulate the $\mathrm{N}$ gaseous losses (ammonia volatilization and denitrification), b) modifying the tipping bucket approach to allow for a temporal delay in the water flow from one soil layer to the other and to avoid abrupt changes of drainage in time, and c) accounting for the temperature effects on the nitrogen transformation parameters. The compartmental model has been implemented in a Matlab code and is available for further test and research on request to the authors. The comparison of the observed and predicted values of drainage and nitrate leaching demonstrates that both models, once calibrated, can be used to evaluate different management strategies of irrigation and fertilization to achieve the goal of reducing nitrogen pollution from agricultural sources without reducing yield.

\section{Acknowledgements}

This work has been partially supported by the Spanish Ministerio de Ciencia e Innovación under projects, MTM2007-64477-AR07 and INIA-RTA 2011-00136-C04-01.

\section{References}

Ahuja, L.R., Nielsen, D.R., 1991. Field soil-water relation. In: Stewart, B.A., Nielsen, D.R. (Eds.), Irrigation of agricultural crops. Series Agronomy no 30, ASA, Madison, WI., pp. 144-190.

Alva, A.K., Paramasivam, S., Fares, A., Obreza, T.A., Schumann, A.W., 2006. Nitrogen best 
management practice for citrus trees II. Nitrogen fate, transport, and components of $\mathrm{N}$ budget. Sci. Hort. 109, 223-233.

Ayers, R.J., Wescott, D.W., 1985. Water quality for agriculture. FAO Irrigation and Drainage Paper $n^{\circ}$ 29, Rome.

Babiker, I.S., Mohamed, A.A., Terao, H., Kato, K., Ohta, K., 2004. Assessment of groundwater contamination by nitrate leaching from intensive vegetable cultivation using geographical information system. Environ. Int. 29, 1009-1017.

Bouwer, H., 1990. Agricultural chemicals and ground water quality. J. Soil Water Conserv. 45, 184-189.

Brady, N.C., Weil, R.R. 2002. The nature and properties of soils. $13^{\text {th }}$ ed. Upper Saddle River, New Jersey, Prentice Hall.

Brisson, N., Mary, B., Ripoche, D., Jeuffroy, M.H., Ruget, F., Nicoullaud, B., Gate, P., Devienne-Barret, F., Antonioletti, R., Durr, C., Richard, G., Beaudoin, N., Recous, S., Tayot, X., Plenet, D., Cellier, P., Machet, J.M., Meynard, J.M., Delécolle, R., 1998. STICS: a generic model for the simulation of crops and their water and nitrogen balances. I. Theory and parameterization applied to wheat and corn. Agronomie 18, 311-346.

Campbell, G., 1974. A simple method for determining unsaturated conductivity from moisture retention data. Soil Sci. 117, 311-314.

Cannavo, P., Recous, S., Parnaudeau, V., Reau, R., 2008. Modeling N dynamics to assess environmental impacts of cropped soils. Adv. Agron. 97, 131-174.

Canter, L.W., 1996. Nitrates in groundwater. CRC, Lewis Publishers, Boca Raton, FL.

Castel, J.R., Bautista, I., Ramos, C., Cruz, G., 1987. Evapotranspiration and irrigation efficiency of mature orange orchards in Valencia (Spain). Irrig. Drainage Syst. 3, 205-217.

Childs, S.W., Hanks, R.J. 1975. Model of soil salinity effects on crop growth. Soil Sci. Soc. Amer. Proc. 39, 617-622.

Contreras, W.A., Lidón, A.L., Ginestar, D., Bru, R., 2009. Compartmental model for nitrogen dynamics in citrus orchards. Math. Comput. Model. 50, 794-805.

D’Odorico, P., Laio, F., Porporato, A., Rodriguez-Iturbe, I., 2003. Hydrologic controls on soil carbon and nitrogen cycles. II. A case study. Adv. Water Resour. 26, 59-70.

DOGV, 2008. ORDEN de 12 de diciembre de 2008, de la Consellería de Agricultura, Pesca y Alimentación, por la que se establece el Programa de Actuación sobre las zonas vulnerables designadas en la Comunidad Valenciana. Diario Oficial de la Generalitat Valenciana 5922, 93425-93436.

DOGV, 2010. ORDEN 7/2010, de 10 de febrero, de la Conselleria de Agricultura, Pesca y 
Alimentación, por la que se aprueba el Código Valenciano de Buenas Prácticas Agrarias. Diario Oficial de la Generalitat Valenciana 6212, 7239-7250.

Doorenbos, J., Pruitt, W.O., 1977. Crop water requirements. FAO Irrigation and Drainage Paper $n^{\circ} 24$, Roma.

5 Dou, H., Alva, A.K., Khakural, B.R., 1997. Nitrogen mineralization from citrus tree residues under different production conditions. Soil Sci. Soc. Am. J. 61, 1226-1232.

Emerman, S.H., 1995. The tipping bucket equations as a model for macropore flow. J Hydrol. $171,23-47$.

Harrison, C.B., Graham, W.D., Lamb, S.T., Alva, A.K., 1999. Impact of alternative citrus

Hoffmann, M., Johnson, J., 1999. A method for assessing generalized nitrogen leaching

Ferrer, E., Pomares, F., Canet, R., Albiach, R., Tarazona, F., 2006. Estudio sobre la incorporación de los restos de poda de cítricos en diferentes municipios de la provincia de Valencia. Levante Agrícola 379, 24-28. management practices on groundwater nitrate in the Central Florida Ridge: II. Numerical modelling. Trans. ASABE 42, 1669-1678. estimates for agricultural land. Environ. Monitor. Assess. 4, 35-44.

Hutson, J.L., Wagenet, R.J., 1991. Simulating nitrogen dynamics in soils using a deterministic model. Soil Use Manage. 7, 74-78.

Jabro, J., Toth, J.D., Dou, Z., Fox, R.H., Fritton, D.D., 1995. Evaluation of nitrogen version of LEACHM for predicting nitrate leaching. Soil Sci. 160, 209-217.

Jeuffroy, H.M., Recous, S., 1999. Azodyn: a simple model simulating the date of nitrogen deficiency for decision support in wheat fertilization. Eur. J. Agron. 10, 129-144.

Johnsson, H., Bergstrom, L., Janson, P.E., Paustian, K., 1987. Simulated nitrogen dynamics and losses in a layered agricultural soil. Agr. Ecosyst. Environ. 18, 333-356.

Jung, Y.W., Oh, D.S., Kim, M., Park, J.W., 2010. Calibration of LEACHN model using LHOAT sensitivity analysis. Nutr. Cycl. Agroecosyst. 87, 261-275.

Keeney, D.R., Nelson, D.W., 1982. Nitrogen - Inorganic forms. In: Page, A.L. (Ed.), Methods of Soil Analysis. Part 2. Am. Soc. Agron., Madison, pp. 643-698.

Kersebaum, K.C., Hecker, J.M., Mirschel, W., Wegehenkel, M., 2007. Modelling water and nutrient dynamics in soil-crop systems: a comparison of simulation models applied on common data sets. In: Kersebaum, K.C., Hecker, J.M., Mirschel, W., Wegehenkel, M. (Eds.), Modelling water and nutrient dynamics in soil-crop systems. Springer, Dordrecht, The Netherlands, pp. 1-17.

Lamb, S.T., Graham, W.D., Harrison, C.B., Alva, A.K., 1999. Impact of alternative citrus management practices on groundwater nitrate in the Central Florida Ridge. I. Field 
investigation. Trans. ASABE 42, 1653-1668.

Legaz, F., Primo-Millo, E., 1988. Normas para la fertilización de los agrios. Fullets Divulgació n5-88. Conselleria d'Agricultura i Pesca. Generalitat Valenciana, 29pp.

Lidón, A., 1994. Lixiviación de nitrato en huertos de cítricos bajo diferentes tratamientos de abonado nitrogenado. PhD Thesis, Universidad Politécnica de Valencia, Spain.

Lidón A., Paches, M., 2005. Uso de un modelo de transporte de agua y solutos como apoyo a la recomendación del abonado nitrogenado en cítricos. Fruticultura profesional 155, 16-

Lidon, A., Bautista, I., de la Iglesia, F., Oliver, J., Llorca, R., Cruz-Romero, G., 2006. Furrow and ridge soil nitrogen mineralization in a surface irrigated artichoke field. Acta Hort. (ISHS) 700, 71-74.

MMA, 2004. Water in Spain. Secretaría de Estado de Aguas y Costas. Madrid. Ministerio de

MMA, 2006. Medio Ambiente en España. Allué R (coord.) Secretaría General Técnica Ministerio de Medio Ambiente. Madrid.

Moreno, R., 2001. Caracterización analítica de residuos orgánicos para su posterior compostaje y aprovechamiento agrícola. Trabajo Final de Carrera, ETSMRE, Universidad Politécnica de Valencia.

Neeteson, J.J., Carton, O.T., 2001. The environmental impact of nitrogen in field vegetable production. Acta Hort. (ISHS) 563, 21-28.

Nendel, C., 2009. Evaluation of Best Management Practices for $\mathrm{N}$ fertilisation in regional field vegetable production with a small-scale simulation model. Eur. J. Agron. 30, 110-118.

Paramasivam, S., Alva, A.K., Prakash, O., Cui, S.L., 1999. Denitrification in the vadose zone and in surficial groundwater of a Sandy entisol with citrus production. Plant Soil 208, 307-319.

Paramasivam, S., Alva, A.K., Fares, A., Sajwan, K.S., 2001. Estimation of nitrate leaching in an Entisol under optimum citrus production. Soil Sci. Soc. Am. J. 65, 914-921.

Porporato, A., D’Odorico, P., Laio, F., Rodríguez-Iturbe, I., 2003. Hydrologic control on soil carbon and nitrogen cycles. I. Modeling scheme. Adv. Water Resour. 26, 45-58.

Primo-Millo, E., Legaz, F., 1993. Fertilización N-P-K en agrios. Levante Agrícola 245, 39-59.

Quiñones, A., Bañuls, J., Primo-Millo, E., Legaz, F., 2003. Effects of $15 \mathrm{~N}$ application frequency on nitrogen uptake efficiency in citrus trees. J. Plant Physiol. 160, 14291434. 
1 Quiñones, A., Martínez-Alcantara, B., Legaz, F., 2007. Influence of irrigation system and fertilization management on seasonal distribution of $\mathrm{N}$ in the soil profile and on $\mathrm{N}$ uptake by citrus trees. Agric. Ecosyst. Environ. 122, 399-409.

Ramos, C., 1988. The use of the chloride balance method for estimating nitrate leaching. In: Jenkinson, D.S., Smith, K.A. (Eds.), Nitrogen efficiency in agricultural soils. Elsevier, Amsterdam, pp. 256-268.

Ramos, C., Agut, A., Lidón, A.L., 2002. Nitrate leaching in important crops of the Valencian Community region (Spain). Environ. Pollut. 118, 215-223.

Saxton, K.E., Rawls, W.J., Romberger, J.S., Papendick, R.I., 1986. Estimating generalized soilwater characteristics from texture. Soil Sci. Soc. Am. J. 50, 1031-1036.

Sempere, A., Oliver, J., Ramos, C., 1993. Simple determination of nitrate in soils by second derivative spectroscopy. J. Soil Sci. 44, 633-639.

Sogbedji, J.M., van Es, H.M., Hutson, J.L., 2001. N fate and transport under variable cropping history and fertilizer rate on loamy and sand clay loam soils: calibration of the LEACHMN model. Plant Soil 229, 57-70.

Sogbedji, J.M., van Es, H.M., Melkonian, J.J., Schindelbeck, R.R., 2006. Evaluation of the PNM model for simulating drain flow nitrate-N concentration under manure-fertilized maize. Plant Soil 282, 343-360.

Vanclooster, M., Viaene, P., Christiaens, K., Ducheyne, S., 1996. WAVE: a mathematical model for simulating water and agrochemicals in the soils and vadose environment. Reference and user's manual (release 2.1), Institute for Land and Water Management, Katholieke Universiteit Leuven, Leuven, Belgium.

Wagenet, R.J., Hutson, J.L., 1989. LEACHM: Leaching Estimation and Chemistry Model: A process based model of water and solute movement, transformations, plant uptake and chemical reactions in the unsaturated zone. Ver. 2. Water Resour. Inst., Cornell University, Ithaca, New York.

Wallach, D., 2006. Evaluating crop models. In: Wallach, D., Makowski, D., Jones, J.W. (Eds.), Working with dynamic crop models. Elsevier Science, Oxford U.K., pp. 11-44.

Webb, T.H., Lilburne, L.R., 1999. Use of the LEACHM model and DRASTIC index to map relative risk of groundwater contamination by pesticide leaching. J. Hydrol. (NZ) 38, 271-288. 
1 Table 1

2 Main characteristics and processes related to water and nitrogen balance and their treatment by the 3 LEACHN and compartmental models.

\begin{tabular}{lll}
\hline Processes & LEACHN & Compartmental model \\
\hline Water related & &
\end{tabular}

Evapotranspiration Potential ET and considering soil water content, root resistance and root density

Water flux

Soil hydraulic parameters

Runoff

Nitrogen related

Input

Nitrogen pools

Plant uptake

Mineralization

Nitrification

Denitrification

$\mathrm{N}$ rate constants adjustment

Leaching

Adsorption

Volatilization
Richards' equation; water content and hydraulic conductivity based on Campbell's equation

The Campbell's coefficients estimated according to Hutson and Wagenet (1991) and saturated hydraulic conductivity estimated by Ahuja and Nielsen method (1991)

A function of maximum infiltration and the rate of water application

Rainwater, irrigation, fertilization, organic amendments

Humus, litter, organic amendments, urea, ammonium and nitrate

A function of $\mathrm{N}$ concentration in soil solution and root water uptake

First order kinetics

Depends on a given potential rate and the actual $\mathrm{NO}_{3}{ }^{-} / \mathrm{NH}_{4}{ }^{+}$ratio

First-order process with respect to nitrate concentration

Temperature $\left(Q_{10}\right)$, water content

Convection-dispersion equation

Adsorption isotherm

First order kinetics with respect to ammonium concentration
Potential ET corrected as a function of soil water content and a minimum soil water storage below which plants cannot extract water

A function of maximum soil water storage held against gravity. No lateral water flux to or from soil is assumed

Estimated after Saxton et al. (1986) and Lidón et al. (1999)

A function of maximum soil water storage

Rainwater, irrigation, fertilization, organic amendments

Humus, litter, microbial biomass, ammonium and nitrate

A function of $\mathrm{N}$ concentration in soil solution and root water uptake

Nonlinear kinetics

Nonlinear kinetics

Not considered

Water content

Determined by concentration in soil solution and drainage

Not considered

Not considered 
Table 2

2 Characteristics of the experimental plot.

Crop

Scion

Rootstock

Planting density

Typical yields

Soil type

Tillage

1 and $3^{\text {th }}$ year

2 year

Irrigation

Method

Period

Average water applied

Measuring method

Fertilizer treatments

Rate

Number applications

Chemical form

Soil sampling

Number of samples

Depth

Frequency

Soil analysis

Gravimetric moisture

Nitrate

Ammonium

Chloride

Meteorological data

Water analysis (average)

Nitrate in rainfall

Chloride in rainfall

Nitrate in irrigation

Chloride in irrigation
Citrus sinensis L. Osbeck cv. Navelina

Citrus aurantium $\mathrm{L}$.

453 trees/ha ( $4.8 \mathrm{~m}$ between rows and $4.6 \mathrm{~m}$ within rows)

35 to $45 \mathrm{t} \mathrm{ha}^{-1}$

Xerofluvent

rototiller and cultivator to break the soil surface crust

non tillage

flood irrigation in basins $\left(3.5 \times 112 \mathrm{~m}^{2}\right)$

April to October (8-10 irrigations)

$58 \mathrm{~mm}$ (with tillage); $32 \mathrm{~mm}$ (non tillage)

Rectangular sharp-crested weir

$\mathrm{N} 1: 150 \mathrm{~kg} \mathrm{~N}^{-1}$ year $^{-1} ; \mathrm{N} 2: 300 \mathrm{~kg} \mathrm{~N}$ ha $^{-1}$ year $^{-1}$

3 (about April, June and August)

ammonium sulphate

three points/tree, in two trees per treatment (Lidón et al., 1999)

$0-30,30-60$ and $60-80 \mathrm{~cm}$

6-7 times per annual season

drying the sample at $105^{\circ} \mathrm{C}$

ultraviolet spectroscopy (Sempere et al., 1993)

Berthelot method (Keeney and Nelson, 1982)

saturated paste extract and a Corning Chloride Analyzer 926

IVIA station (4 km away from experimental site)

$5 \mathrm{mg} \mathrm{NO}_{3}{ }^{-} \mathrm{L}^{-1}$

$12 \mathrm{mg} \mathrm{Cl}^{-} \mathrm{L}^{-1}$

$83 \mathrm{mg} \mathrm{NO}_{3}^{-} \mathrm{L}^{-1}$ (groundwater), $17 \mathrm{mg} \mathrm{NO}_{3}^{-} \mathrm{L}^{-1}$ (surface water)

$136 \mathrm{mg} \mathrm{Cl}^{-1} \mathrm{~L}^{-1}$ (groundwater), $125 \mathrm{mg} \mathrm{Cl}^{-1} \mathrm{~L}^{-1}$ (surface water)

Others 
1 Table 3

2 Soil physical and chemical properties of the experimental plot.

\begin{tabular}{lccc}
\hline & \multicolumn{3}{c}{ Depth $(\mathrm{cm})$} \\
\cline { 2 - 4 } Soil properties & $0-30$ & $30-60$ & $60-80$ \\
\hline Texture (\%) & 67 & 35 & 24 \\
\multicolumn{1}{c}{ Sand } & 17 & 35 & 39 \\
$\quad$ Silt & 16 & 30 & 37 \\
Textural class $(\mathrm{USDA})$ & sandy loam & clay loam & clay loam \\
Organic C $\left(\mathrm{g} \mathrm{C} \mathrm{kg}^{-1}\right)$ & 9.0 & 8.0 & 8.0 \\
Organic N $\left(\mathrm{g} \mathrm{N} \mathrm{kg}^{-1}\right)$ & 1.0 & 0.9 & 0.9 \\
pH $(\mathrm{KCl})$ & 7.5 & 7.5 & 7.5 \\
CEC $\left(\mathrm{cmol}_{\mathrm{c}} \mathrm{kg}^{-1}\right)$ & 8.8 & 12.1 & - \\
Bulk density $\left(\mathrm{Mg} \mathrm{m}^{-3}\right)$ & 1.25 & 1.51 & 1.73 \\
\hline
\end{tabular}

3

4 Table 4

5 Soil hydraulic, crop and nitrogen related parameters values used in LEACHN.

\begin{tabular}{|c|c|}
\hline Parameter & Value \\
\hline \multicolumn{2}{|l|}{ Soil hydraulic } \\
\hline \multicolumn{2}{|l|}{ Water retention parameters } \\
\hline Air entry value $(\mathrm{kPa})^{\mathrm{a}}$ & $-0.840 /-1.960 /-3.070$ \\
\hline Exponent in Campbell's equation ${ }^{\mathrm{a}}$ & $3.59 / 5.91 / 9.33$ \\
\hline \multicolumn{2}{|l|}{ Crop } \\
\hline Roots distribution $(\%)^{\mathrm{a}}$ & $51 / 40 / 9$ \\
\hline Maximum ratio of actual to potential transpiration & 1.1 \\
\hline Root resistance & 125 \\
\hline Ground cover fraction & 0.85 \\
\hline Annual $\mathrm{N}$ uptake $\left(\mathrm{kg} \mathrm{ha}^{-1}\right)$ & 200 \\
\hline \multicolumn{2}{|l|}{ Nitrogen ${ }^{b}$} \\
\hline Partition coefficient $\mathrm{NH}_{4}{ }^{+}-\mathrm{N}\left(\mathrm{L} \mathrm{kg}^{-1}\right)$ & 2.6 \\
\hline Partition coefficient $\mathrm{NO}_{3}^{-}-\mathrm{N}\left(\mathrm{L} \mathrm{kg}^{-1}\right)$ & 0.0 \\
\hline $\mathrm{C} / \mathrm{N}$ ratio (biomass and humus) & 10 \\
\hline $\mathrm{Q}_{10}$ & 2.0 \\
\hline Base temperature at which rate constants apply $\left({ }^{\circ} \mathrm{C}\right)$ & 20.0 \\
\hline $\begin{array}{l}\text { High end of optimum water content range, air-filled } \\
\text { porosity }\end{array}$ & 0.08 \\
\hline Lower end of optimum water content ( $\mathrm{kPa})$ & -300 \\
\hline Minimum matric potential for transformations ${ }^{\mathrm{c}}(\mathrm{kPa})$ & -1500 \\
\hline Relative transformation rate at saturation & 0.6 \\
\hline Ammonia volatilization $\left(\right.$ day $\left.^{-1}\right)$ & 0.5 \\
\hline Denitrification half-saturation constant $\left(\mathrm{mg} \mathrm{L}^{-1}\right)$ & 10.0 \\
\hline Limiting $\mathrm{NO}_{3}{ }^{-} / \mathrm{NH}_{4}{ }^{+}$ratio in solution for nitrification & 8.0 \\
\hline
\end{tabular}


2 Table 5

3 Crop and nitrogen parameters values used in the compartmental model and not subject to calibration.

\begin{tabular}{lc}
\hline Parameter & Value \\
\hline Roots distribution $(\%)^{\mathrm{a}}$ & $65 / 30 / 5$ \\
Ground cover $(\%)$ & 0.85 \\
Pan coefficient $\mathrm{k}_{\mathrm{p}}$ & 0.815 \\
C/N ratio litter & 28 \\
C/N ratio humus & 10 \\
C/N ratio microbial biomass & 8 \\
Microbial biomass death rate $\left(\mathrm{day}^{-1}\right)$ & 0.00137 \\
\hline${ }^{\mathrm{a}}$ Values for the three soil layers $0-30,30-60$ and $60-80 \mathrm{~cm}$, respectively.
\end{tabular}

5

6

\section{Table 6}

7 Water related parameters, $\mathrm{N}$ transformation rate constants obtained after calibration for soil water and 8 mineral nitrogen content.

\begin{tabular}{|c|c|c|}
\hline Variable & $\mathrm{LEACHN}^{\mathrm{a}}$ & Compartmental model $^{\mathrm{a}}$ \\
\hline Sat. hydraulic conductivity $\left(\mathrm{mm} \mathrm{d}^{-1}\right)$ & $4400 / 500 / 132$ & - \\
\hline \multicolumn{3}{|l|}{ Water storage $(\mathrm{mm})$} \\
\hline $\mathrm{L}_{\max }$ & - & $110 / 117 / 70$ \\
\hline $\mathrm{L}_{\min }$ & - & $19 / 40 / 37$ \\
\hline $\mathrm{L}_{\mathrm{fc}}$ & - & $60 / 60 / 43$ \\
\hline $\mathrm{L}_{\text {crit }}$ & - & $34.2 / 60 / 43$ \\
\hline Synthesis efficiency factor & 0.30 & - \\
\hline Respiration factor & - & 0.50 \\
\hline Humification fraction & 0.45 & 0.30 \\
\hline \multicolumn{3}{|l|}{ Mineralization rate constants $\left(\mathrm{day}^{-1}\right)$} \\
\hline Litter $^{\mathrm{b}}$ & $(2.0 / 2.0 / 2.0) \times 10^{-3}$ & $(0.6 / 4.0 / 4.0) \times 10^{-3}$ \\
\hline Humus $^{\mathrm{b}}$ & $(9.0 / 1.0 / 4.0) \times 10^{-5}$ & $(6.8 / 0.04 / 2.0) \times 10^{-5}$ \\
\hline Nitrification rate constants ${ }^{\mathrm{b}}\left(\right.$ day $\left.^{-1}\right)$ & $(6.0 / 6.0 / 6.0) \times 10^{-1}$ & $(6.0 / 0.7 / 0.5) \times 10^{-1}$ \\
\hline Denitrification rate constants $\left(\mathrm{day}^{-1}\right)$ & $0.2 / 0.3 / 0.001$ & - \\
\hline $\begin{array}{l}{ }^{\mathrm{a}} \text { Values for the three soil layers } 0-30,30 \\
\mathrm{~b} \text { Although the original units of the con } \\
\text { those used by the LEACHN model to fac }\end{array}$ & $\begin{array}{l}\text { ind } 60-80 \mathrm{~cm} \text {, respectivel } \\
\text { mental model are differe } \\
\text { e comparison. }\end{array}$ & hey have been transformed \\
\hline
\end{tabular}


$1 \quad$ Table 7

2 Statistics for the comparison between observed and simulated values for soil water storage $(\mathrm{mm})$ and mineral nitrogen content $\left(\mathrm{kg} \mathrm{N}\right.$ ha $\left.{ }^{-1}\right)$ for the calibration and 3 validation periods in both models.

\begin{tabular}{|c|c|c|c|c|c|c|c|c|c|c|}
\hline \multirow[b]{3}{*}{ Statistics } & \multicolumn{8}{|c|}{ Calibration period } & \multirow{2}{*}{\multicolumn{2}{|c|}{$\begin{array}{c}\text { Validation period } \\
0-80 \mathrm{~cm} \\
\end{array}$}} \\
\hline & \multicolumn{2}{|c|}{$0-30 \mathrm{~cm}$} & \multicolumn{2}{|c|}{$30-60 \mathrm{~cm}$} & \multicolumn{2}{|c|}{$60-80 \mathrm{~cm}$} & \multicolumn{2}{|c|}{$0-80 \mathrm{~cm}$} & & \\
\hline & LEACHN & Compartm. & LEACHN & Compartm. & LEACHN & Compartm. & LEACHN & Compartm. & LEACHN & Compartm. \\
\hline \multicolumn{11}{|l|}{ Water } \\
\hline$\overline{\text { Mean }}$ difference & -0.7 & 0.2 & -3.1 & 2.7 & 9.1 & 10.1 & -5.0 & 2.4 & -4.0 & 0.6 \\
\hline RMSE & 4.0 & 5.4 & 6.8 & 3.6 & 9.8 & 11.0 & 12.6 & 9.1 & 13.7 & 10.1 \\
\hline RRMSE & 0.13 & 0.18 & 0.14 & 0.07 & 0.20 & 0.22 & 0.11 & 0.08 & 0.11 & 0.08 \\
\hline$A I$ & 0.95 & 0.94 & 0.76 & 0.91 & 0.55 & 0.49 & 0.87 & 0.93 & 0.91 & 0.95 \\
\hline \multicolumn{11}{|l|}{ Nitrogen (N2) } \\
\hline Mean difference & 18.9 & 6.1 & -6.0 & -6.5 & -4.8 & 0.8 & 8.1 & 0.4 & -37.5 & -14.8 \\
\hline RMSE & 22.8 & 10.4 & 6.6 & 13.8 & 9.5 & 7.7 & 18.4 & 20.0 & 68.2 & 76.2 \\
\hline RRMSE & 0.43 & 0.20 & 0.24 & 0.50 & 0.41 & 0.33 & 0.18 & 0.19 & 0.36 & 0.40 \\
\hline$A I$ & 0.85 & 0.97 & 0.90 & 0.80 & 0.33 & 0.19 & 0.91 & 0.93 & 0.76 & 0.73 \\
\hline \multicolumn{11}{|l|}{ Nitrogen (N1) } \\
\hline Mean difference & - & - & - & - & - & - & - & - & 23.5 & 15.0 \\
\hline RMSE & - & - & - & - & - & - & - & - & 41.5 & 45.3 \\
\hline RRMSE & - & - & - & - & - & - & - & - & 0.39 & 0.42 \\
\hline$A I$ & - & - & - & - & - & - & - & - & 0.61 & 0.65 \\
\hline
\end{tabular}

$$
\begin{array}{r}
5 \\
6 \\
7 \\
8 \\
9 \\
10 \\
11
\end{array}
$$


2 Table 8

3 Water balance components measured and simulated ( $\mathrm{mm})$.

\begin{tabular}{|c|c|c|c|c|c|c|}
\hline \multirow{2}{*}{$\begin{array}{l}\text { Water balance } \\
\text { component }\end{array}$} & \multicolumn{2}{|c|}{ Measured } & \multicolumn{2}{|c|}{ Compartmental model } & \multicolumn{2}{|c|}{ LEACHN model } \\
\hline & Periods ${ }^{\text {a }}$ & $\begin{array}{c}\text { Total } \\
\text { (three years) }\end{array}$ & Periods ${ }^{a}$ & $\begin{array}{c}\text { Total } \\
\text { (three years) }\end{array}$ & Periods ${ }^{a}$ & $\begin{array}{c}\text { Total } \\
\text { (three years) }\end{array}$ \\
\hline \multicolumn{7}{|l|}{ Input $^{\mathrm{b}}$} \\
\hline Rainfall & 388 / 460 / 222 & 1070 & 388 / 460 / 222 & 1070 & 388 / 460 / 222 & 1070 \\
\hline Irrigation & $221 / 303 / 413$ & 937 & $221 / 303 / 413$ & 937 & $221 / 303 / 413$ & 937 \\
\hline Total input & 609 / 763 / 635 & 2007 & 609 / 763 / 635 & 2007 & 609 / 763 / 635 & 2007 \\
\hline \multicolumn{7}{|l|}{ Output } \\
\hline ET & $489 / 630 / 566^{c}$ & $1685^{\mathrm{c}}$ & $471 / 575$ / 566 & 1613 & 499 / 629 / 626 & 1754 \\
\hline Drainage & $128 / 110 / 78$ & 316 & 123 / 125 / 68 & 316 & 122 / 100 / 20 & 242 \\
\hline Runoff & - & - & $37 / 39 / 0$ & 76 & $5 / 3 / 3$ & 11 \\
\hline $\begin{array}{l}\text { Total output } \\
\text { Change }\end{array}$ & 617 / 740 / 644 & 2001 & $631 / 739$ / 634 & 2005 & 626 / 732 / 649 & 2007 \\
\hline$\Delta$ Soil water & $-8 / 23 /-9$ & 6 & $-22 / 24 / 1$ & 3 & $-18 / 31 /-14$ & -1 \\
\hline
\end{tabular}

4 a 31 May 91 - 10 April 92/11 April 92 - 5 April 93/ 6 April 93-3 March 94

$5{ }^{\mathrm{b}}$ Rainfall and Irrigation data are inputs to both models and equal to the measured values.

$6 \quad{ }^{\mathrm{c}}$ Calculated by water balance assuming that runoff is negligible 
1 Table 9

2 Nitrogen balance for the low (N1) and high (N2) fertilization rate treatments $\left(\mathrm{kg} \mathrm{N} \mathrm{ha}^{-1}\right)$.

\begin{tabular}{|c|c|c|c|c|c|c|}
\hline \multirow[b]{2}{*}{$\begin{array}{l}\text { N balance } \\
\text { component }\end{array}$} & \multicolumn{2}{|c|}{ Measured } & \multicolumn{2}{|c|}{ Compartmental model } & \multicolumn{2}{|c|}{ LEACHN model } \\
\hline & Periods $^{\text {a }}$ & $\begin{array}{c}\text { Total } \\
\text { (three years) }\end{array}$ & Periods $^{\text {a }}$ & $\begin{array}{c}\text { Total } \\
\text { (three years) }\end{array}$ & Periods $^{a}$ & $\begin{array}{c}\text { Total } \\
\text { (three years) }\end{array}$ \\
\hline \multicolumn{7}{|l|}{ N1 treatment } \\
\hline \multicolumn{7}{|l|}{$\overline{\text { Input }}$} \\
\hline Rainfall & $4 / 5 / 2$ & 11 & $4 / 5 / 2$ & 11 & $4 / 5 / 2$ & 11 \\
\hline Irrigation & $25 / 10 / 16$ & 51 & $25 / 10 / 16$ & 51 & $25 / 10 / 16$ & 51 \\
\hline Fertilizer & $30 / 170 / 150$ & 350 & $30 / 170 / 150$ & 350 & $30 / 170 / 150$ & 350 \\
\hline Mineralization & - & - & $75 / 119 / 116$ & 310 & $119 / 133 / 123$ & 375 \\
\hline \multicolumn{7}{|l|}{ Output } \\
\hline Plant uptake & - & - & 152 / 182 / 162 & 496 & 169 / 205 / 199 & 573 \\
\hline Leaching & 44 / 42 / 37 & 123 & 49 / 98 / 49 & 196 & 45 / 62 / 13 & 120 \\
\hline Volatilization & - & - & - & - & $5 / 18 / 18$ & 41 \\
\hline Denitrification & - & - & - & - & $3 / 8 / 1$ & 12 \\
\hline \multicolumn{7}{|l|}{ Change } \\
\hline$\underset{\mathrm{N} 2}{\Delta \mathrm{Nmin}} \underset{\text { treatment }}{\Delta}$ & $-11 / 20 / 31$ & \multicolumn{5}{|c|}{ N2 treatment } \\
\hline \multicolumn{7}{|l|}{ Input } \\
\hline Rainfall & $4 / 5 / 2$ & 11 & $4 / 5 / 2$ & 11 & $4 / 5 / 2$ & 11 \\
\hline Irrigation & $25 / 10 / 16$ & 51 & $25 / 10 / 16$ & 51 & $25 / 10 / 16$ & 51 \\
\hline Fertilizer & $80 / 320 / 300$ & 700 & 80 / 320 / 300 & 700 & 80 / 320 / 300 & 700 \\
\hline Mineralization & - & - & 62 / 63 / 91 & 216 & 118 / 133 / 123 & 374 \\
\hline \multicolumn{7}{|l|}{ Output } \\
\hline Plant uptake & - & - & 109 / 335 / 318 & 514 & 173 / 204 / 200 & 577 \\
\hline Leaching & $68 / 73 / 77$ & 218 & 72 / 171 / 82 & 325 & $66 / 126 / 36$ & 228 \\
\hline Volatilization & - & - & - & - & $10 / 37 / 36$ & 83 \\
\hline Denitrification & - & - & - & - & $7 / 22 / 4$ & 33 \\
\hline \multicolumn{7}{|l|}{ Change } \\
\hline$\Delta \mathrm{Nmin}$ & $-11 / 21 / 160$ & 170 & $-57 / 38 / 158$ & 139 & $-29 / 77 / 165$ & 213 \\
\hline
\end{tabular}

3 a 31 May 91 - 10 April 92 / 11 April 92 - 5 April 93/ 6 April 93- 3 March 94 
1 Table 10

2 Different scenarios evaluated with LEACHN and compartmental model in a three year period.

\begin{tabular}{|c|c|c|c|c|c|}
\hline Scenario & Management & $\begin{array}{l}\text { N rate fertilization } \\
\left(\mathrm{kg} \mathrm{N} \mathrm{ha}^{-1} \operatorname{year}^{-1}\right)\end{array}$ & $\begin{array}{l}\text { Number of } \\
\text { applications }\end{array}$ & $\begin{array}{c}\text { Chemical } \\
\text { form }^{\text {a }}\end{array}$ & $\begin{array}{c}\text { Irrigation }(\mathrm{mm}) \\
\text { (three years) }\end{array}$ \\
\hline $\mathrm{Sc0}$ & Conventional fertilization and irrigation & 300 & 3 & $\mathrm{AS}$ & 937 \\
\hline Sc1 & Conventional fertilization and increased irrigation $(+10 \%)$ & 300 & 3 & AS & 1031 \\
\hline $\mathrm{Sc} 2$ & Conventional fertilization and reduced irrigation $(-10 \%)$ & 300 & 3 & AS & 843 \\
\hline Sc3 & Reduced fertilization $(-10 \%)$ & 270 & 3 & AS & 937 \\
\hline Sc4 & Reduced fertilization (-10\%) and two chemical forms & 270 & 3 & $\mathrm{AS}-\mathrm{AN}$ & 937 \\
\hline Sc5 & $\begin{array}{l}\text { Reduced fertilization }(-10 \%) \text {, two chemical forms and } \\
\text { increased number of applications }\end{array}$ & 270 & 4 & AS - AN & 937 \\
\hline Sc6 & Reduced fertilization (-10\%) and reduced irrigation (-10\%) & 270 & 3 & AS & 843 \\
\hline $\mathrm{Sc} 7$ & Rate fertilization according to VCGAP & 230 & 3 & AS & 937 \\
\hline $\mathrm{Sc} 8$ & $\begin{array}{l}\text { Rate fertilization according to VCGAP and two chemical } \\
\text { forms }\end{array}$ & 230 & 3 & AS - AN & 937 \\
\hline Sc9 & $\begin{array}{l}\text { Rate fertilization according to VCGAP, two chemical forms } \\
\text { and increased number of applications }\end{array}$ & 230 & 4 & AS - AN & 937 \\
\hline Sc10 & $\begin{array}{l}\text { Rate fertilization according to VCGAP and reduced irrigation } \\
(-10 \%)\end{array}$ & 230 & 3 & AS & 843 \\
\hline
\end{tabular}

\footnotetext{
${ }^{\mathrm{a}} \mathrm{AS}=$ ammonium sulphate; $\mathrm{AN}=$ ammonium nitrate; VCGAP = Valencian Code of Good Agricultural Practices
} 


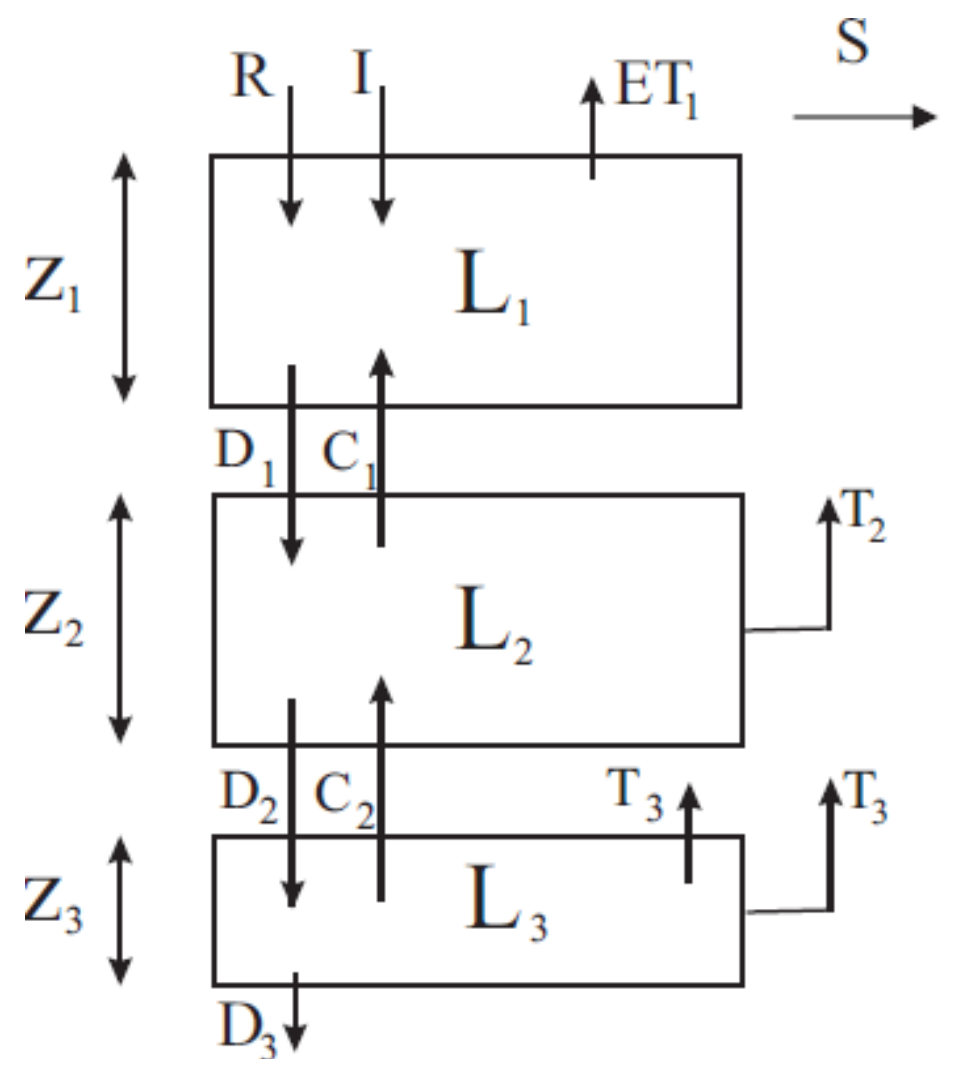

4 Fig. 1. Three layers soil water module. $\mathrm{R}$ indicates rainfall, $\mathrm{I}$ irrigation, $\mathrm{S}$ runoff, $\mathrm{ET}_{1}$ evapotranspiration 5 in layer one, $\mathrm{T}_{2}$ and $\mathrm{T}_{3}$ transpiration in layers two and three, $\mathrm{L}_{1}, \mathrm{~L}_{2}$ and $\mathrm{L}_{3}$ soil water content in each layer, $6 \quad D_{1} D_{2}$ and $D_{3}$ drainage in each layer and $C_{1}$ and $C_{2}$ capillary rise. 

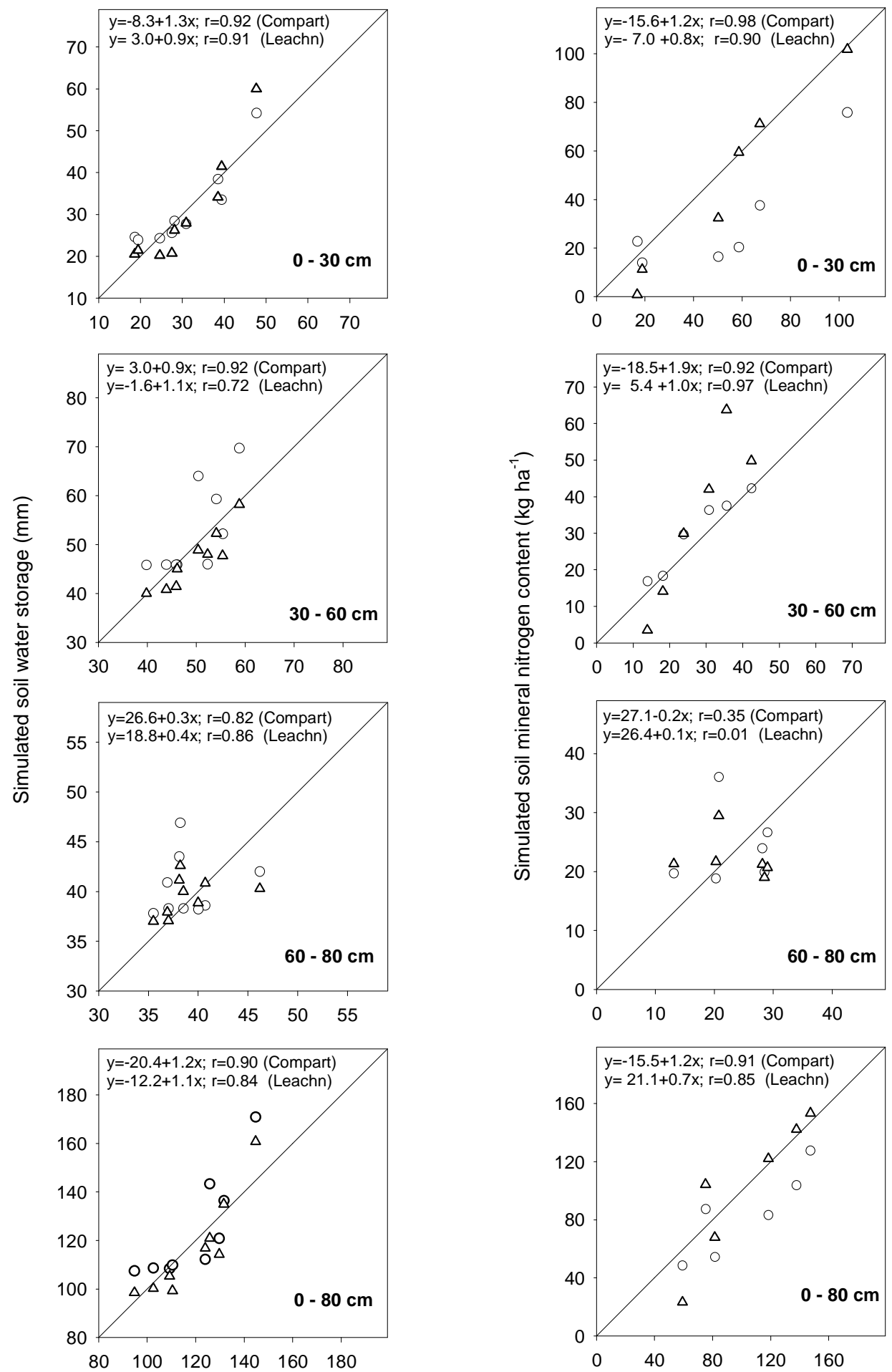

Measured soil water storage $(\mathrm{mm})$

Measured soil mineral nitrogen content $\left(\mathrm{kg} \mathrm{ha}^{-1}\right)$

$\Delta \quad$ Compartmental model

- LEACHN model

Fig. 2. 1:1 plot and regression of measured and simulated soil water storage (left) and soil mineral nitrogen values (right) in each soil layer after model calibration (using data from first year and high nitrogen fertilizer rate, $\mathrm{N} 2$ ). 


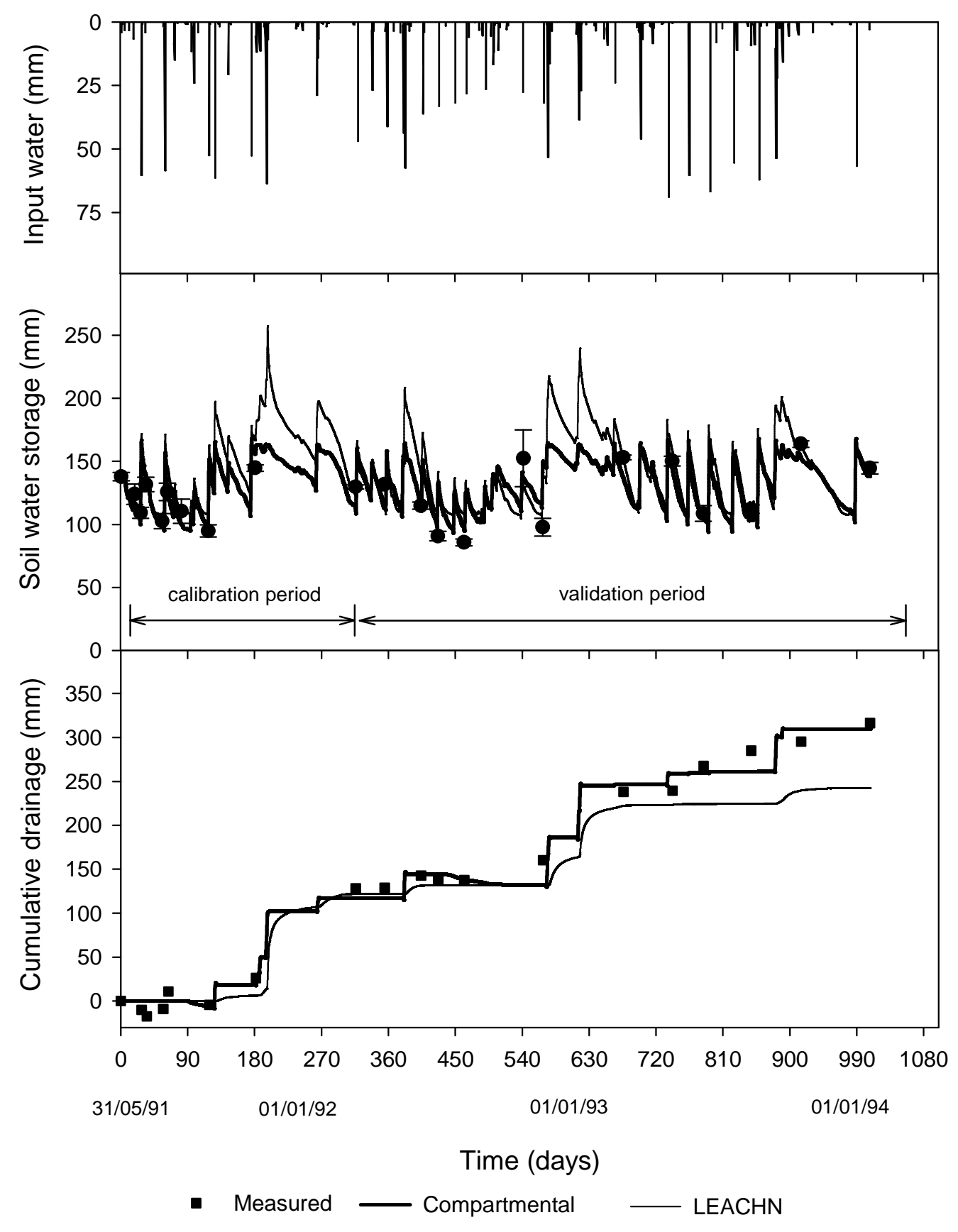

Fig. 3. Soil water storage and cumulative drainage measured at $80 \mathrm{~cm}$ depth and simulated with LEACHN and with the compartmental model during the calibration period (first year) and validation period (second and third year). At the top, water input by rainfall and irrigation. Each data of soil water content is the average of four points (see table 2). Vertical bars represent the standard error. 

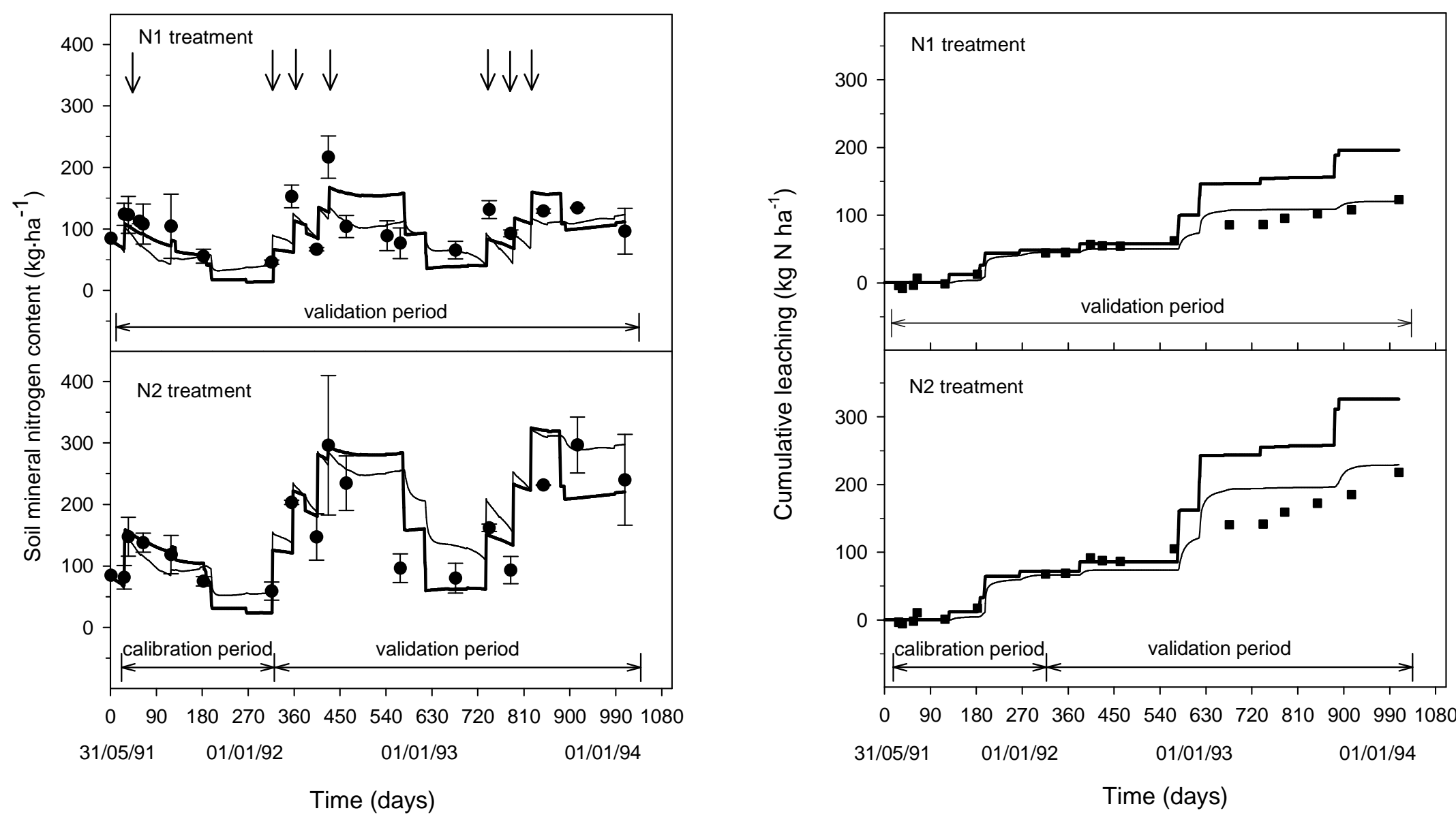

- Measured Compartmental - LEACHN

2 Fig. 4. Mineral nitrogen content in the soil profile and cumulative nitrate leaching at $80 \mathrm{~cm}$ soil depth measured and simulated with the LEACHN and the compartmental models during the calibration and validation periods in treatments N1 and N2. The arrows indicate the fertilizer applications in both treatments. Each data of Nmin is the average of two points (see table 2). Vertical bars represent the standard error. 


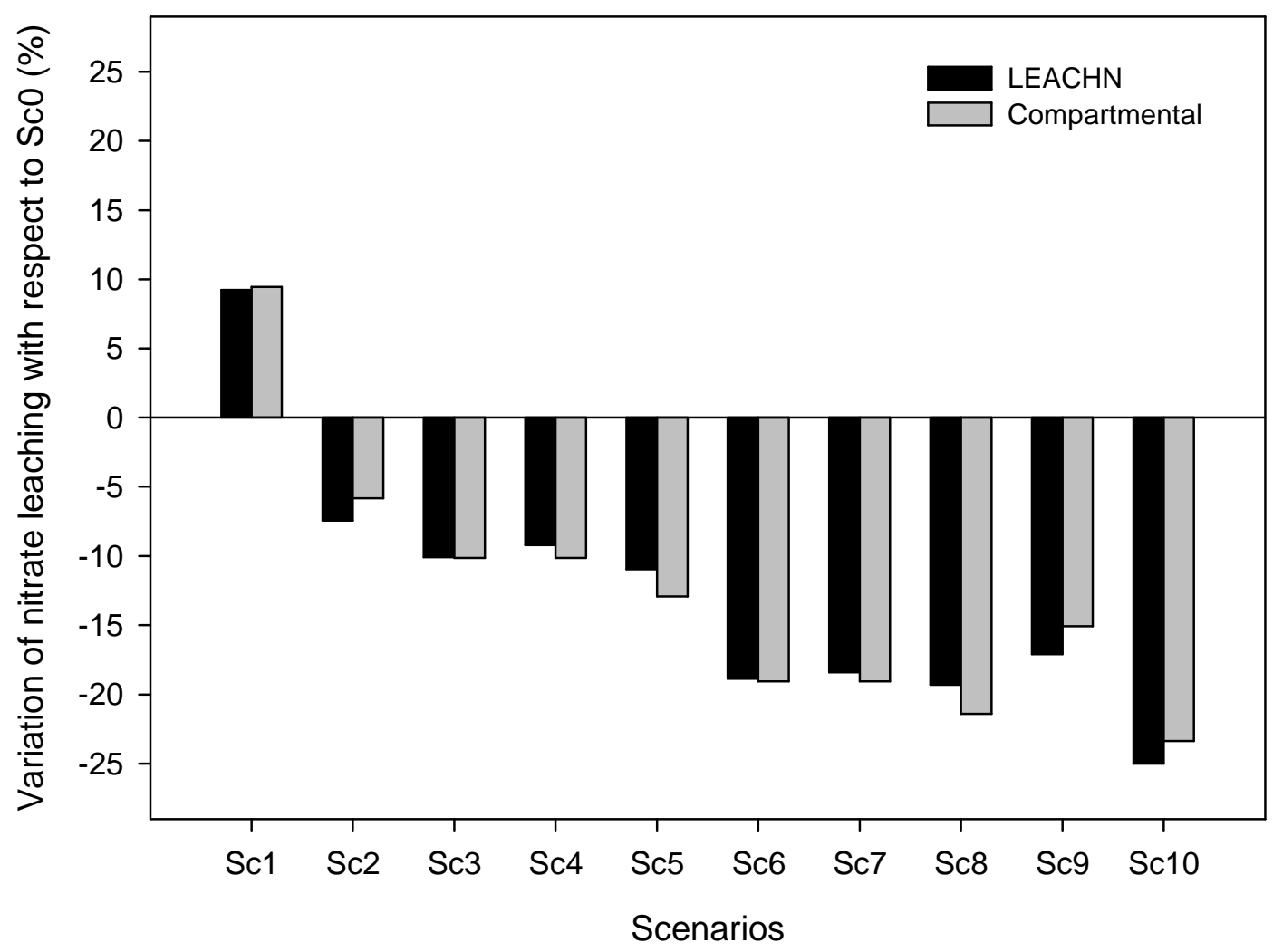

Fig. 5. Variation in nitrate leaching simulated with both models under the different fertilization and irrigation management scenarios assessed (see Table 10). 